\title{
"Revising the Literary Map": Three Anthologies of Indian Writing and Instances of Literary Commitment
}

Julie Beluau

\section{OpenEdition} Journals

Electronic version

URL: https://journals.openedition.org/ces/6129

DOI: $10.4000 /$ ces. 6129

ISSN: 2534-6695

Publisher

SEPC (Société d'études des pays du Commonwealth)

\section{Printed version}

Date of publication: 1 September 2015

Number of pages: $33-43$

ISSN: 2270-0633

\section{Electronic reference}

Julie Beluau, "'Revising the Literary Map": Three Anthologies of Indian Writing and Instances of Literary Commitment", Commonwealth Essays and Studies [Online], 38.1 | 2015, Online since 10 April 2021, connection on 10 July 2021. URL: http://journals.openedition.org/ces/6129 ; DOI: https:// doi.org/10.4000/ces.6129

\section{(c) (i) (9)}

Commonwealth Essays and Studies is licensed under a Licence Creative Commons Attribution - Pas d'Utilisation Commerciale - Pas de Modification 4.0 International. 


\section{"Revising the Literary Map": Three Anthologies of Indian Writing and Instances of Literary Commitment}

This article focuses on anthologies as a site of commitment for three writers who, because of the "absent authority" of Indian criticism (Perry), are also critics and literary historians of Indian writing in English. In their anthologies, the poets and novelists revise the literary map and trace alternative creative lineages in order to locate their own literary practices and, in doing so, never fail to recast the terms of the critical debates on the genre(s), language(s), and major features of Indian literature in English.

Whether in their works of fiction, poetry or criticism Indian English writers have from the start been committed to defining the outlines of their literature and discussing the major issues underlying Indian writing in English. In a humorous anecdote, in which a certain sense of despair shows through the irony of the tone, the poet Adil Jussawalla discusses the critical reception of Arvind Krishna Mehrotra's influential anthology of modern Indian poetry and points at the relative absence of professional critics in India, a role too often taken up by the poets themselves: ${ }^{1}$

When the Oxford India Anthology of Twelve Modern Indian Poets turned up at various newspaper and magazine offices recently, sighs of dismay swept the country. Editors responsible for commissioning book reviews saw that, in one stroke, they had lost thirteen potential reviewers of the book - the twelve poets it represented and its editor Arvind Krishna Mehrotra. How and where were they going to find other reviewers? (Maps 56)

Indian writers proposed, very early on, their own surveys of the field of Indian English writing. P. Lal's controversial Modern Indian Poetry: An Anthology and a Credo (1969) - conceived as a response to the Bengali writer Buddhadeva Bose's remark that "IndoAnglian' poetry is a blind alley, lined with curio shops, leading nowhere" (Lal 5) - was followed by numerous attempts to counter his lack of "selectivity and discrimination" (King 29). ${ }^{2}$ From Adil Jussawalla's New Writing in India (1974) to Amit Chaudhuri's Picador Book of Modern Indian Literature (2001), poets and novelists have also sought to correct the partial and prejudiced view of Indian fiction and non-fiction traditions both in India and the West. To interrogate the possible figures of postcolonial writers' commitment, this article will analyse more specifically three ground-breaking and controversial anthologies of literature compiled by contemporary Indian English writers and critics who consciously aim at "revis[ing] the literary map" (Mehrotra, Twelve Modern 8): Arvind Krishna Mehrotra's Oxford India Anthology of Twelve Modern Indian Poets (1992), ${ }^{3}$ Salman

1. In “Preface to 3 Poets: Melanie Silgardo, Raul D'Gama Rose, Santan Rodrigues," Jussawalla foregrounds another major characteristic of Indian publishing and reveals how Indian poets, because publishers often "fail to materialise," rely on one another to publish their works: "My intention is really to show that the phenomenon of poets publishing themselves and other poets is not a secondary feature of Indian publishing, but the chief one" (Maps 269-70).

2. Arvind Krishna Mehrotra's irreverent answer to P. Lal's questionnaire conveys the sense that the younger generation of poets no longer felt the need to justify their writing: "why write in english? [...] the question is like asking why do you wear a black coat and why not a red one. how the hell are you interested anyway" (Lal 303, the absence of capital letters in the original has been kept).

3. In 1990, Mehrotra edited an earlier anthology entitled Twenty Indian Poems, in which he collected poems for the Indian student whose curriculum was then still dominated by the writings of the canonical English writers: "Twenty Indian Poems has been prepared with the undergraduate Indian student in mind. [...] Nobody can study, much less enjoy, a page 
Rushdie and Elizabeth West's Vintage Book of Indian Writing, 1947-1997 (1997), and Amit Chaudhuri's Picador Book of Modern Indian Literature published in 2001. Since they were - and still are - so influential in India and the West and marked turning points in the constitution of Indian literary history, but also because they are intertextually related, this article proposes to compare the three anthologies and the competing traditions invented by the three writers-critics in their collections. By studying the contexts of publication, the selections of texts and authors, the prefaces and introductions to the volumes but also their polemical relationships to contemporary or previous anthologies, this article will argue that the anthology is a privileged site of commitment for Indian English writers. Following Mehrotra's assertion that "so far as Indian poetry in English is concerned its canon has been created by the anthologists" (de Souza 107), I will demonstrate how anthologies provide the writers with the opportunity to construct or deconstruct canons, trace alternative genealogies for their creative practice and engage with the main debates over the themes, language(s) and dominant genre(s) of Indian writing. I will compare the three anthologies under study in order to examine how the writers are committed to shaping the history of Indian writing in English, grounding my argument on the premise that anthologies are central to what Antoine Compagnon describes, in the preface to L'Histoire littéraire des écrivains, as an "alternative" literary history (Debaene 8), i.e. the literary history forged by novelists, poets and essayists as opposed to academics' versions of the history of literature. By studying how the three anthologies respond to one another and relate to other shape-giving anthologies and how the three writers conceive of the role of an anthology and justify their intervention, this article will try to trace what could be called "genealogies of commitment" and analyse more specifically the nature of Mehrotra's, Rushdie's and Chaudhuri's critical gestures.

\section{Contexts of Publication}

In the introductions or prefaces to their works, Arvind Krishna Mehrotra, Salman Rushdie and Amit Chaudhuri justify their interventions and give readers their conceptions of the role of an anthology. For Mehrotra, Twelve Modern Indian Poets was called for by the lack of good criticism on Indian poetry ${ }^{4}$ and the necessity to circulate, in this form, texts that have either been overlooked by critics or have long been out-of-print: "To edit an anthology is an opportunity to revise the literary map, bring neglected works back in circulation, and shift the emphasis from certain poets to others" (8). In a later interview with the poet Eunice de Souza, he again evoked the necessity of anthologies to circulate poems: "In a situation where individual volumes, many of them published from small presses, have always been hard to locate, the anthology was the only means of making a poet's work available outside a coterie" (de Souza 107-8). The title of Salman Rushdie and Elizabeth West's anthology The Vintage Book of Indian Writing, 1947-1997 makes it clear that the collection was meant to coincide with the fifty-year anniversary of Indian independence and celebrate the event by taking a look at Indian literature since 1947 (the title of the American edition of the book is even more explicit in that respect).

of literature if it makes them feel inadequate, and the undergraduate Indian student, perversely given John Milton's 'On the Morning of Christ's Nativity' to read, is made to feel just this" (Twenty Indian Poems 1).

4. In the short preface to the anthology, Mehrotra sharply denounces his fellow academics' failure to meaningfully discuss Indian poetry in English: “The criticism of Indian poetry in English that has come out of our universities' English Departments is both voluminous and of inferior quality, and is best left alone" (xiii). 
The introduction ${ }^{5}$ also acknowledges that the aim of the anthology was to record "the flow of that good writing that has become a flood" (xxi) and thus counter, in Rushdie's words, the "received critical wisdom within India itself" (x) that rejects Indian English writing as alien. ${ }^{6}$ In the Picador Book of Modern Indian Literature published a few years later, Amit Chaudhuri foregrounds his idiosyncratic approach of the anthologist's job - an approach that was later criticized by some reviewers. He offers a very personal selection and a subjective perspective on modern Indian literature by creating entries that highlight certain literary and cultural movements (particularly "The Bengal Renaissance and After") or Indian languages ("Hindi," "Urdu," "English"), or by putting together texts according to their area of cultural origin (the rather vague "The South" includes four extracts by writers in Kannada, Malayalam, and Tamil) or even genre ("Pages from Autobiography"). If some categories appear hasty and the anthology gives pride of place to Bengali and English while omitting other Indian languages altogether as Girish Karnad rightly points out, Chaudhuri does not deny that he had no ambition to compile a "representative anthology" (xxxii) for lack of space and access to good translations in some languages but also, and perhaps more importantly, because the shape of the anthology very much bears the imprint of his own Bengali and English "sensibility" (xxxii).

In the introduction to Women Writing in India, Susie Tharu and K. Lalita warn the reader that the extracts collected in their anthology should not be regarded as "monuments" to an existing literature but rather as "documents" highlighting what is at stake in the writings (39). This distinction is interesting in the light of the works studied here and particularly of Rushdie and West's anthology. ${ }^{7}$ Since it celebrates the "flood" of good Indian writing in English on the occasion of the fifty years of the nation and opens with the founding "Tryst with Destiny" speech pronounced by the first Prime Minister of India on the eve of Independence, ${ }^{8}$ we can wonder to what extent the collected works - and the anthology itself - correspond to Susie Tharu and K. Lalita's notion of "monument." If it does possess a celebratory tone, Rushdie's anthology is however more than a "monument" to Indian literature and the nation when, paradoxically, he addresses the question of what is absent from the anthology. The Vintage Book of Indian Writing is more a document and less of a monument when it engages critically with what Salman Rushdie left out from his collection and outlines problems of literary history, as when he evokes Indian poetry in English for example. The notion of "monument" also plays out in Arvind Krishna Mehrotra's reflection on the ambivalence of anthologies. In Twelve Modern Indian Poets, he expresses his regret at saying in an earlier essay ("The Emperor Has No Clothes," 1982) that "anthologies are graveyards, and the anthologist's job is to see only the best corpses get in" (1). For Mehrotra, if they can

5. The introduction was also published in slightly different versions in The New Yorker in 1997 and in Rushdie's collection of non-fiction Step Across This Line (2002) under the title "Damme, This Is the Oriental Scene for You!"”

6. Rushdie clearly states that he speaks from the West, looking at Indian literature from England: "Perhaps it does seem, to some 'home' commentators, that a canon is being foisted on them from outside. The perspective from the West is rather different. [...] It feels as if the East is imposing itself on the West, rather than the other way round" (xiv).

7. Susie Tharu and K. Lalita's volumes bearing little resemblance to the anthologies under study in which considerations on the gender of the writers is noticeably absent, this article only retains the distinction drawn by the authors to conceptualize their anthologizing enterprise.

8. Placed at the very beginning of the anthology, Nehru's speech, which celebrates Independence as the moment "when the soul of a nation, long suppressed, finds utterance" (Vintage Book 1, emphasis added), seems to be at the foundation of both the Indian nation and Indian literature in English for Rushdie. 
sometimes be compared to tombs - in Twenty Indian Poems he refers to poems that have been "anthologized-to-death" (1) - anthologies are also necessary to prevent writers from dying a second time because of critical neglect. ' What prevents an anthology from becoming a "monument" in the sense of a graveyard is then what Mehrotra calls "responsible criticism" ("The Emperor" 161): the relentless and meaningful reading and discussion of texts, authors, and literary problems. In a controversy with the poet R. Parthasarathy about the necessity of getting rid of the uncritical praise of A.K. Ramanujan's poems, he declared: "Are they going to be buried like a treasure and guarded by a hound; worshipped like a village deity [...] Or are they going to be read and commented on, praised and dispraised, as all poems are?" ("The Emperor" 163)

In other words, the anthology must perform a critical function, what Amit Chaudhuri underscores when he asserts that Mehrotra's anthology is "not so much a collection as a critical essay" (Clearing 144), a conception that also applies to his own anthology. ${ }^{10}$ For both Mehrotra and Chaudhuri, an anthology must be "canon-shaping" and "canonbreaking" (Partial Recall 2), it must be part of a process of "disowning" certain traditions and "recovering" others (Clearing 40) and be engaged in shaping a literature. The anthology is thus an essay insofar as it is the space where the anthologist questions and tries out ideas; and indeed, for Amit Chaudhuri, it is a means to address Indian literature as a problem, not a fact: ${ }^{11}$

To ask, however, "Is there an Indian literature?" or "Does an Indian literature exist?" is not necessarily to be insulting, but to invite one to conceptualize the matter in a new way. I had attempted to ask this question with my anthology; some readers, though not all, had taken the anthology to be a statement rather than a question. (Clearing 142)

\section{Genealogies of Commitment}

If the anthology is a privileged site of commitment for Arvind Krishna Mehrotra, Salman Rushdie and Amit Chaudhuri, it is necessary to examine the polemical relationships engaged in the different anthologies and first, to analyse the dialogic relationship between the three writers themselves since they write with and against one another. It is perhaps less true of Mehrotra and Rushdie who are relatively silent on each other's works - even though this is certainly telling in itself. The only acknowledgement comes from Arvind Krishna Mehrotra's criticism of Rushdie's anthology:

Salman Rushdie was only speaking the truth when he said in the introduction to The Vintage Book of Indian Writing (1997) that "there has long been a genuine problem of

9. Mehrotra's essays on Indian literary history are full of life and death metaphors. See for instance: "And the dead writer is now twice dead"; "Everyone dies, but some people, writers particularly, get a second life. [...] Not in India, though. Here, whether writer or not, you live only once" (Partial Recall 2, 133). The image recurs in Chaudhuri's words when talking, interestingly, about Mehrotra's discussion of the poem Jejuri: "the poem was to receive, decisively, a fresh lease of life, and the oxygen of good criticism, from Mehrotra in his anthology, The Oxford India Anthology of Twelve Modern Poets" (Clearing 228).

10. Conceived as "an extended essay with very large quotations" (Clearing 144), Chaudhuri's anthology is itself composed of individual essays: the three pieces that feature in the introduction - "Modernity and the Vernacular" (originally published in the Times Literary Supplement in 1997), "The Construction of the Indian Novel in English" (which also appeared in the TLS in 1999), and the "Note on the Selection" - as well as the short essays introducing individual authors.

11. To his critical engagement with modern Indian literature, Chaudhuri opposes what he calls the "triumphalist" conceptualisation of postcolonial literature: “To ask, for instance, 'Is there such a thing as post-colonial literature?' or 'Does a post-colonial literature exist?' is problematic, but the questions, of course, have a triumphalist answer, to do with the 'writing back' the clearing of space, we've all heard about" (Clearing 142). 
translation in India... and it is possible that good writers have been excluded by reason of their translators' inadequacies rather than their own." There are graver problems with his selection, but that is another matter. (de Souza 108)

On the other hand, Amit Chaudhuri clearly reveals his position with regard to both Mehrotra's and Rushdie's anthologies. In an essay entitled "Travels in the Subculture of Modernity," he places himself in the lineage of Mehrotra's commitment to Indian literary history and talks at length about the influence of his anthology:

A literature, like an anthology, is not a collection of extraordinary achievements but a field of interrelationships; and it is part of the anthologist's job - his or her critical function - to contribute to interpreting and even creating one possible version of that field. The first anthology that had performed, for me, this critical function in 'Indian writing' was Arvind Krishna Mehrotra's Twelve Modern Indian Poets. (Clearing 143)

On the contrary, Amit Chaudhuri's Picador Book of Modern Indian Literature can be regarded as a refutation of Salman Rushdie's anthology - as well as a challenge to the postcolonial canon. Even though Chaudhuri never refers to Rushdie's Vintage Book of Indian Writing, the reader never doubts the connection, especially, paradoxically, when he states that "this anthology is not a riposte to any other anthology" (xxxiii), thus drawing attention, without naming him, to "Rushdie's contentious presence" in the background (Gandhi and Karnad) - an intuition confirmed later by the reference to Salman Rushdie's "throwaway comment that little of value has been written in the Indian languages in the last fifty years" (Vintage Book xxxiii).

Arvind Krishna Mehrotra's Twelve Modern Indian Poets is certainly a case in point of the way new anthologies come to question an earlier canon. It is indeed a riposte to, or in Amit Chaudhuri's words, a mirror and a refutation (Clearing 144), of another Indian poet's anthology published in 1976, namely R. Parthasarathy's Ten Twentieth-Century Indian Poets. If Mehrotra's "twelve" Indian poets replace R. Parthasarathy's "ten" poets, the main difference and object of controversy do not however concern the selection of authors and texts - both reject the influence of Sarojini Naidu, Toru Dutt and Aurobindo Ghose, and they include more or less the same poets, with the difference that Mehrotra shifts the emphasis from Nissim Ezekiel towards A.K. Ramanujan and Arun Kolatkar. ${ }^{12}$ Rather, and this critical move is also manifest in the title, it is Mehrotra's construction, in the space of the anthology, of a "modern" Indian English poetry that constitutes the real departure from R. Parthasarathy's canon. In his anthology, Arvind Krishna Mehrotra foregrounds the networks of affiliations of the modern Indian poets with Eliot, Pound and the Beats and expands, for instance, on the manner in which Arun Kolatkar's poetry reveals a "reverence towards things" (54) that the poetry of Ezra Pound or William Carlos Williams also showed. But most importantly, Mehrotra denies R. Parthasarathy's contention that the poets' language is characterized by a form of alienation - which could retrospectively be qualified as postcolonial - which limits their achievements. For Arvind Krishna Mehrotra, the poets' language is a modern idiom marked by the gap between language and experience, a gap which explains the vitality of modern Indian poetry in English. ${ }^{13}$ In that respect, Mehrotra's anthology can

12. R. Parthasarathy, Kamala Das, Shiv Kumar and Gieve Patel are absent from Mehrotra's anthology which, on the other hand, includes Arun Kolatkar and Dilip Chitre in the canon.

13. Compare Mehrotra's words: "The rift is between language and experience rather than between a particular language and, in Parthasarathy's thoughtful phrase, 'everyday Indian reality," (“The Emperor" 184) with R. Parthasarathy's 
be considered a continuation of the work initiated by the poet Adil Jussawalla with New Writing in India (1974), in which he presented Western readers with "new" or modern works in English and in translation in order to contradict the assumption that Indian modernity is a "parasitic" imitation of Western modernity.

\section{Revising the Literary Map, Recasting the Debates}

As Suman Gupta argued in an article devoted to the 1970s anthologies of Indian poetry in English, the selective process involved in any anthology ultimately aims at revising the canon of that writing: "The justifications for selectivity almost invariably provide the justifications for canonicity in terms of aesthetic value, representativeness, and tradition" (102). Moreover, the three anthologists' critical interventions consist in outlining a different canon in which to place their own literary practice; in other words, they choose their own contemporaries and ancestors ${ }^{14}$ in order to situate themselves as writers. Salman Rushdie seeks to show how, from the start, Indian English writing was preoccupied with the question of the nation. His own production is thus to be located alongside the different writings which share this concern, such as, for instance, the political memoirs of Nehru's niece, Nayantara Sahgal, Upamanyu Chatterjee's short story set against the backdrop of Indira Gandhi's assassination, Saadat Hasan Manto's account of the Partition of India in "Toba Tek Singh" or the epic rewriting of twentieth-century Indian history in Shashi Tharoor's The Great Indian Novel. Arvind Krishna Mehrotra argues that modern Indian English poets, like him, had to make their pacts "in their own backyard" (by drawing from the tradition of bhakti poetry for instance) and "overseas" (with the Beats, Eliot, and Pound) (Twelve Modern 2), and his analysis of Arun Kolatkar's visual poetry, A.K. Ramanujan's craft and Dilip Chitre's bilingual sensibility clearly reflects his own poetic preferences. Amit Chaudhuri's recovery of modern Indian traditions is also the gesture of “an Indian writer who doesn't trace, as he probably should, his creative lineage to Salman Rushdie and the mandatory 'hybrid' post-colonial usages of English, but to a variety of (often conflicting) sources and forebears" (Clearing 11-2).

More particularly, the three anthologies under scrutiny take up the major issues of Indian writing and seek to realign the critical discourse on the genre(s), language(s) and trope(s) of Indian literature. If Mehrotra is exclusively concerned with poetry, Rushdie's anthology includes extracts from different fictional and non-fictional genres such as memoirs, novels, and short stories, but leaves aside Indian English poetry:

[...] while it was impossible, for reasons of space, to include a representative selection of modern Indian poetry, it was evident to us that the rich poetic traditions of India continued to flourish in many of the sub-continent's languages, whereas the Englishlanguage poets, with a few distinguished exceptions (Arun Kolatkar, A.K. Ramanujan, Jayanta Mahapatra, to name just three), did not match the quality of their counterparts in prose. (xi)

assertion: "The Indian who uses the English language feels, to some extent, alienated" (Ten Twentieth-Century Indian Poets $3)$.

14. The phrase is borrowed from Lætitia Zecchini, who emphasizes in her latest work the role of Indian poet-critics in the invention of their traditions and asserts that contemporary Indian English poets' translations of medieval bhakti verse constitute acts of literary affiliations across time: "Contemporary poets choose their contemporaries and ancestors. More accurately still, they make contemporaries of their ancestors" (75). 
But it is Amit Chaudhuri who pointedly reflects on the question of the genres of Indian literature. In The Picador Book of Modern Indian Literature, he questions the predominance of the novel in critical discussions of Indian English writing, a predominance which is also that of the novel understood as the Rushdian novel - turned by Western readership and critics into the literary model after which contemporary Indian writers in English fashion their playful, irreverent, and extensive narratives characterized by linguistic hybridity and the representation of the nation. According to Chaudhuri, "Midnight's Children having been erected as a sort of gigantic edifice that all but obstructs the view of what lies behind it" (xxiii), it was necessary to recover, through his new anthology, modern traditions of the short form, the memoir, and the essay ${ }^{15}$ which suggest India by ellipsis rather than represent its heterogeneity mimetically. By collecting extracts from novels (such as R.K. Narayan's The English Teacher) or short stories (Rabindranath Tagore's "The Postmaster") which frustrate the expectations of postcolonial critics, Amit Chaudhuri clears a space for his own kind of writing - a kind of writing which also finds some space in Rushdie's anthology as the latter discusses R.K. Narayan's "gentle, lightly funny art" (xviii) and Amit Chaudhuri's "languorous, elliptic, beautiful prose" (xxii) that seem so antithetical to his own postmodern style.

In their anthologies, the writers also take a stand on the use of the English language by Indian writers. If all three agree on the unique characteristics of the Indian writers' English idiom, they seem, however, to trace the pioneering use of this "Indian English" to different predecessors. In Twelve Modern Indian Poets, Arvind Krishna Mehrotra quotes a letter from his friend Agha Shahid Ali in which he expands on the influence of Salman Rushdie's language for the poets:

I think we in the subcontinent have been granted a rather unique opportunity: to contribute to the English language in ways that the British, the Americans, and the Australians, also the Canadians, cannot. We can do things with the syntax that will bring the language alive in rich and strange ways, and though poetry should have led the way, it is a novelist, Salman Rushdie, who has shown the poets $a$ way: he has, to quote an essay I read somewhere, chutnified English. (4) ${ }^{16}$

If Mehrotra does not clearly take position here, the anthology itself, which features poets who started to write before Rushdie, seems however to qualify Agha Shahid Ali's assertion. On the other hand, Rushdie demonstrates the ground-breaking role of another novelist's language, G.V. Desani's hybrid idiom, in the process of "chutnification" of the English language:

Hatterr's dazzling, puzzling, leaping prose is the first genuine effort to go beyond the Englishness of the English language. His central figure, "fifty-fifty of the species," the half-breed as unabashed anti-hero, leaps and capers behind many of the texts in this book. Hard to imagine I. Allan Sealy's Trotter-Nama without Desani. My own writing, too, learned a trick or two from him. (xviii)

15. A significant portion of the book is devoted to essays on Indian culture and literature by major practitioners of a genre also favoured by Amit Chaudhuri (see Bankimchandra Chatterjee's "A Popular Literature for Bengal," A.K. Ramanujan's "Is There An Indian Way of Thinking?," or Arvind Krishna Mehrotra's "The Emperor Has No Clothes" for instance).

16. Salman Rushdie uses the word "chutnification" at the end of Midnight's Children (1981). In the novel, Saleem Sinai, the narrator, works in a pickle factory during the day and tells his story and the history of the Indian nation to his lover, Padma, at night. Rushdie's "chutnification" refers to the process of preserving memories and the act of recounting them in a hybrid language: "Every pickle-jar (you will forgive me if I become florid for a moment) contains, therefore, the most exalted of possibilities: the feasibility of the chutnification of history; the grand hope of the pickling of time! I, however, have pickled chapters" (642). 
If Amit Chaudhuri also argues that English is an Indian language, he strongly rejects, in his anthology, the "chutnified" language promoted by Salman Rushdie that dominates the critical doxa on Indian English writing:

One of the subtlest ways, indeed, in which the multilingual imagination enters an Indian text has to do with the use of English words - not transmuted or "appropriated and subverted for the post-colonial's own ends," as the current dogma has it, but, estrangingly, in their ordinary and standard forms; yet this is a practice whose import has been insufficiently acknowledged or studied. The peculiar excitement of the poetry that Ramanujan, Arvind Mehrotra or Dom Moraes (to take only three examples) wrote in the 1960 s and 70s derived not so much from their, to use Rushdie's word, "chutnification" of the language, but, in part, from the way they used ordinary English words like "door," "window," "bus," "doctor," "dentist," "station," to suggest a way of life. (xxviii) ${ }^{17}$

Indeed, Chaudhuri controversially relocates the first successful appropriation of English in Indian English poetry - examples of which he, surprisingly, leaves out of his anthology of modern Indian literature - as Jeet Thayil also does in his anthology of contemporary Indian poets. According to the latter, the poets' pioneering role in shaping a distinctive idiom has been wrongly attributed to novelists: "Before novelists discovered Indian English, Derozio had already been there and so had Arun Kolatkar and Nissim Ezekiel. But the new ground they were instrumental in mapping ended up being claimed for fiction" (23).

The relationship between English and the vernacular languages in Indian literature and within the Indian English text is also one of the central concerns of the anthologies and anthologists under study. On this issue, one remembers Salman Rushdie's polemical claim:

$[T]$ he prose writing - both fiction and non-fiction - created in this period by Indian writers working in English, is proving to be a stronger and more important body of work than most of what has been produced in the 16 "official languages" of India, the so-called "vernacular languages," during the same time; and, indeed, this new, still burgeoning, "Indo-Anglian" literature represents perhaps the most valuable contribution India has yet made to the world of books. (Vintage Book $\mathrm{x}$ )

If Rushdie's position created an uproar - among the numerous critics, Adil Jussawalla, the editor of New Writing in India, declared that Rushdie's assertion was "hasty and ill-informed" (Maps 49) - it is, however, an ambiguous remark since within the same introduction he qualifies his "large claim" by acknowledging the influence his "Indian tongues" bore on his imagination:

[A]s a writer, I have been partly formed by the presence, in my head, of that other music, the rhythms, patterns and habits of thought and metaphor of my Indian tongues. What I am saying is that there is not, need not be, should not be, an adversarial relationship between English-language literature and the other literatures of India. (xvi)

Rushdie's problematic claim and the subsequent reduction of "Indian writing" to "Indian writing in English" within the West partly explains Amit Chaudhuri's decision to include texts translated from the vernaculars in his mirror anthology. In it, he operates what he calls a "slight tipping of the scale towards 'regional' or 'vernacular' writing"

17. Chaudhuri's assertion about the subtle ways in which the Indian traditions register on the Indian English text echoes Mehrotra's claim that "[t]he other tradition does not enter a poem by Ramanujan, Kolatkar, or Ali in the guise of a god, a river, a place, a cow named Gopi, or a Tipu Sultan; nor as a poetic shell, a rubai, a dohä, a vacana, or abhanga" (Twelve Modern 6). 
(xxxii) in order to recover the importance of translation in Indian literature and Indian English writing. In Twelve Modern Indian Poets, Mehrotra also engages a reflection on the relation between English and the vernacular languages in Indian literature. Through an analysis of Arun Kolatkar's "Three Cups of Tea," he reveals how multilingualism and processes of translations are at the core of Indian English poetry: "The poem is written in Bombay Hindi, published in Kolatkar's book of Marathi poems, translated by him into American English, and, rightly, has been included in an anthology of Indian verse in English [...]. 'Three Cups of Tea' suggests the idea that all languages are perhaps one language" (3-4)..$^{18}$

As Susie Tharu and K. Lalita pointed out, the creation of anthologies and the shaping of Indian literary canons have from the second half of the twentieth-century been closely intertwined with the question of the nation: "In most languages, the literary canons had been established in the early 1950s, shortly after Independence. They were therefore charged with constructing an imagined community and sculpting the new citizen" (xvi). In "Reinscribing Nation-People in Anthologies of Indian English Poetry," Suman Gupta argues that the 1970s anthologies of Indian English poetry were preoccupied with the reinscription of the space of the nation in Indian literature and the question of the "Indianness" of the texts. R. Parthasarathy's anthology, published in 1976, is a case in point; in the introduction to his selection he makes the following statement: "Any evaluation of Indian verse is usually bedevilled by the question of national identity. Many poets in this selection will be found to be preoccupied with it" (5). On the contrary, Mehrotra, compiling his anthology at the beginning of the 1990s, veers away from the question of the nation, as Gupta also underlines. In Twelve Modern Indian Poets, as argued earlier, the focus is not so much on the expression of a postcolonial alienation, as on the expression of the Indian poets' modern sense of estrangement. In the anthology, Mehrotra clearly resists conceptions of Indian English poetry and language that tend to "narrowly equate Indian poetry with Indianness" (5). Once again, it seems that Amit Chaudhuri's objection to the idea that the representation of the nation is a major characteristic of Indian English writing cannot fully be understood unless we bear in mind how Salman Rushdie's anthology foregrounds the issue of the nation in Indian English writing. Against Rushdie, Amit Chaudhuri suggests that Indian English literature engages with the idea of the nation more obliquely:

It is worth remembering that those who write in the languages of India, whether that happens to be English or one of the modern "vernaculars," do not necessarily write about "India" or a national narrative [...] but about cultures and localities that are both situated in, and disperse the idea of, the nation. (Picador Book xxiv)

Thus, both Arvind Krishna Mehrotra and Amit Chaudhuri are committed to revising the centrality of the nation and the sense of (postcolonial) estrangement in Indian English literary history, as also shown by the work of Lætitia Zecchini, whose reflection on Indian poetry in English, and particularly Arun Kolatkar, participates in the recovery of alternative modern traditions that the narrative of postcoloniality accounts for only partially. ${ }^{19}$

18. Mehrotra pushes the analysis further in the essay "What Is An Indian Poem?" (Arun Kolatkar).

19. In La Modernité littéraire indienne, Zecchini states: "contemporary Indian poetry in English is less about "writing back' to the former colonial power than about struggling against, coming to terms with and engaging with the many facets of the self, which include, but are not limited to, History and the colonial legacy" (73-4, my translation). 
In the introduction to The Vintage Book of Indian Writing, Salman Rushdie draws attention to the impossible task of the anthologist of Indian literature:

Fifty years of work, by four generations of writers, is impossible to summarise, especially when it hails from that huge crowd of a country (close to a billion people at the last count), that vast, metamorphic, continent-sized culture that feels, to Indians and visitors alike, like a non-stop assault on the senses, the emotions, the imagination and the spirit. (ix)

If Indian literature is impossible to anthologise, then the relevance of such works lies elsewhere: in the critical interventions of the anthologists who delineate alternative cartographies of Indian English writing in order to situate themselves as writers, and thus contribute to the critical discussion of their literature. If Salman Rushdie and Elizabeth West outline challenging issues of Indian writing in English - such as the decisive question of translation - Arvind Krishna Mehrotra and Amit Chaudhuri are more clearly committed, in their anthologies, to recasting the terms of the critical debate by constructing a history of Indian writing shaped by "the idiom of modernity" (Picador Book xx).

Julie BeLUAU

Université Paris 8

\section{Works Cited}

Castaing, Anne, Lise Guilhamon, and Lætitia Zecchini, eds. La Modernité littéraire indienne: perspectives postcoloniales. Rennes: PU Rennes, 2009.

Chaudhuri, Amit, ed. The Picador Book of Modern Indian Literature. London: Picador, 2001.

-. Clearing a Space: Reflections on India, Literature and Culture. Witney, UK: Peter Lang, 2008.

Debaene, Vincent et alii, eds.. L'Histoire littéraire des écrivains. Paris: PU Paris-Sorbonne, collection "Lettres françaises," 2013.

De SouzA, Eunice. "Arvind Krishna Mehrotra." Talking Poems: Conversations with Poets. New Delhi: Oxford UP, 1999. 99-109.

GandHI, Leela, and Girish Karnad. "Re-presenting 'India." The Hindu, 2001. < http://www.thehindu. com/thehindu/2001/08/19/stories/1319067g.htm>. Consulted 4 June 2015.

GUPTA, Suman. "Reinscribing Nation-People in Anthologies of Indian English Poetry." The Journal of Commonwealth Literature 31.2 (1996): 101-15.

Jussawalla, Adil, ed. New Writing in India. London: Penguin, 1974.

—. Maps for a Mortal Moon: Essays and Entertainments. Ed. Jerry PINTO. New Delhi: Aleph, 2014.

KING, Bruce. Modern Indian Poetry in English. 1987. New Delhi: Oxford UP, 1994.

LaL, P., ed. Modern Indian Poetry in English: An Anthology and a Credo. 1969. Calcutta: Writers Workshop, 1971.

Mehrotra, Arvind Krishna. "The Emperor Has No Clothes." 1980-1982. Partial Recall: Essays on Literature and Literary History. New Delhi: Permanent Black, 2012. 147-95.

—, ed. Twenty Indian Poems. 1990. New Delhi: Oxford UP, 2011.

-. The Oxford India Anthology of Twelve Modern Indian Poets. 1992. New Delhi: Oxford UP, 2012.

—. Arun Kolatkar, Collected Poems in English. Tarset, Northumberland: Bloodaxe, 2010.

—. Partial Recall: Essays on Literature and Literary History. New Delhi: Permanent Black, 2012.

Parthasarathy, R., ed. Ten Twentieth-Century Indian Poets. 1976. New Delhi: Oxford UP, 1994.

Perry, John Oliver. Absent Authority: Issues in Contemporary Indian English Criticism. New Delhi: Sterling, 1992.

Rushdie, Salman, and Elizabeth West, eds. The Vintage Book of Indian Writing, 1947-1997. London: Vintage, 1997.

—. Mirrorwork: 50 Years of Indian Writing, 1947-1997. New York: Owl Books, 1997.

Rushdie, Salman. Midnight's Children. 1981. London: Vintage, 2008.

—. Imaginary Homelands: Essays and Criticism, 1981-1991. 1991. London: Vintage, 2010.

—. Step Across This Line: Collected Non-Fiction, 1992-2002. London: Jonathan Cape, 2002. 
"Revising the Literary Map"

Tharu, Susie, and K. LaLITA, eds. Women writing in India: 600 BC to the Early Twentieth Century. London: HarperCollins, 1993.

-. Women writing in India: The Twentieth Century. London: HarperCollins, 1993.

THAYIL, Jeet. The Bloodaxe Book of Contemporary Indian Poets. Tarset: Bloodaxe, 2008.

ZeCchini, Lætitia. Arun Kolatkar and Literary Modernism in India: Moving Lines. New York: Bloomsbury Academic, 2014. 